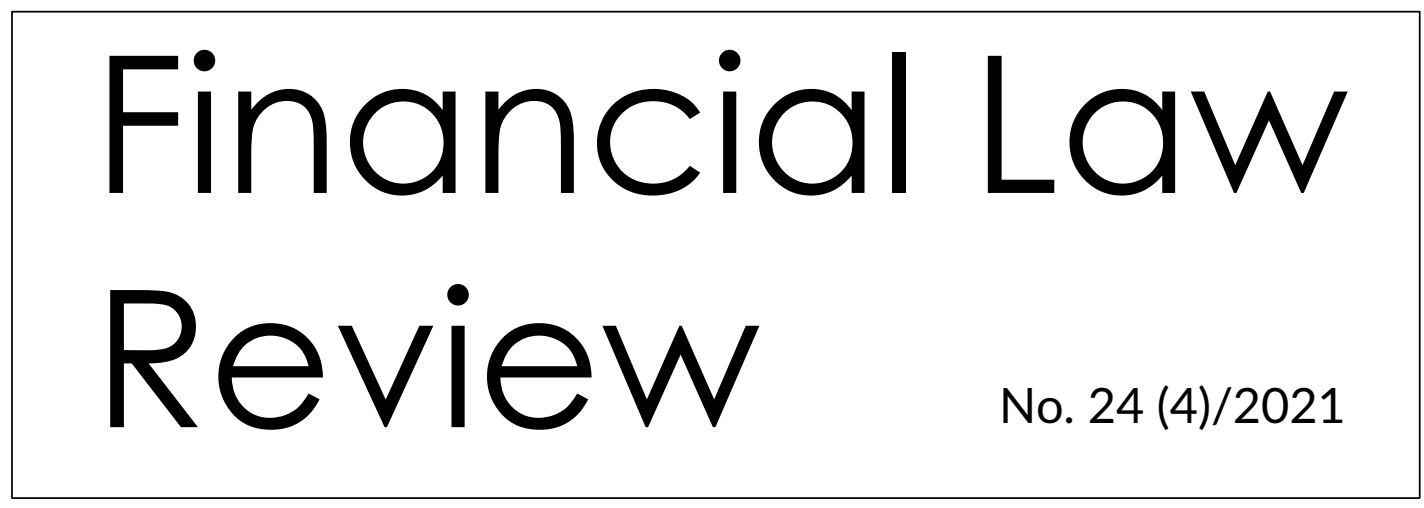

UNIVERSITY OF GDAŃSK • MASARYK UNIVERSITY • PAVEL JOZEF ŠAFÁRIK UNIVERSITY • UNIVERSITY OF VORONEZH

http://www.ejournals.eu/FLR

MAREK KALINOWSKI*, EWA PREJS**

\title{
DEVELOPING THE CONCEPT OF A TAX LAW RELATIONSHIP - ASSUMPTIONS CONCERNING SCIENTIFIC RESEARCH ON THIS ISSUE
}

\begin{abstract}
The concept of legal relationship is a tool that lawyers use to describe the legal situation in which entities find themselves due to applicable legal norms. It is therefore a tool for practical analysis of legal norms. The concept of a legal relationship and other legal concepts related to it are used by a lawyer to determine what rights and obligations a particular entity has in a given legal system in relation to the situation of another entity. In other words, it serves to describe the interdependence of the legal situation of entities due to applicable legal norms. Analysis of the legal relationship and related concepts are also useful for researching the behavior of some entities towards others due to applicable legal norms. The concept of legal relationship and the concepts associated with it are therefore a tool for analyzing law in action, thanks to which it is possible to solve a number of legal problems arising in the practice of applying law. It is important for those branches of law in which there are correlations between legal situations of entities of these branches of law. Therefore, it is
\end{abstract}

\footnotetext{
* Professor in law, holds the position of full-time professor at the Nicolaus Copernicus University in Torun (Poland). His main research interests lie in the field of tax law and theory of law, focusing in particular on the general theory of tax liabilities and interpretation of law.

Contact email: mkal@umk.pl, ORCID: 0000-0003-1106-4387.

** Holds degree in law and a PhD in law from the Nicolaus Copernicus University in Torun (Poland). She has worked with the Department of Public Finance Law of the Faculty of Law and Administration of the Nicolaus Copernicus University since 2007 as a lecturer and a post-doctoral researcher. She has published and lectured widely on issues of Polish, international, and European taxation. Contact email: eprejs@umk.pl, ORCID: 0000-0003-2784-2227.
} 
also important for the tax law and tax research, in which there are relations between the state and taxpayers and other entities of tax law.

Although from the most general point of view the structure of the legal relationship may seem to be very similar, however, legal relations in particular branches of law have their own characteristics. This diversity results from the fact that the content of elements determining specific legal relations in these branches of law is different, such as: the subject of the law, facts causing the creation and termination of the legal relationship as well as the content of the rights and obligations of the parties to this relationship. Research on these elements of the legal relationship allows to achieve specific theoretical and practical goals. Due to the fact that they are embedded in applicable law, they allow to build a model of legal relationship, which becomes a tool for practical analysis of applicable law. Secondly, their study allows to deepen knowledge of the characteristics of individual elements of this relationship, such as the subjects of this right. Thanks to this, it is possible to decide what features an entity should have to be able to become the owner of the rights or obligations of a given branch of law, including tax law. The structure of subjectivity in this branch of law is significantly different from the legal subjectivity of civil law. They also allow to catch the relationships between individual rights and individual rights and obligations regulated in a given branch of law. Finally, they allow to understand the premises that give rise to the rights and obligations incumbent on the subjects of a given branch of law. This in turn allows for an in-depth analysis of the tax law norms themselves, as well as views on individual institutions of this law and their critical analysis, as well as a critical analysis of the views of case law on these legal institutions. In the field of tax law science of various countries, models of a tax law relationship have been already created, which allow ordering and analysis of tax law norms. However, many other countries as the Polish tax law science did not pay much attention to this issue of tax law. Therefore, in many countries the most general model of tax law relationship created by the theory of law is used. The same has happened in Polish tax law science. However, this is an insufficient model, as it requires taking into account the state of tax legislation and the specifics of its regulations. Hence, considerations of tax law doctrine's sometimes lack consistency due to the lack of an appropriate research tool in the form of a tax law relationship model. They also often conflict with each other, because the starting points for the analyses are different. Therefore, further research on tax law relationship is necessary in this field.

This paper presents the assumptions concerning scientific research on developing the concept of a tax law relationship.

Key words: tax law, tax law relationship, tax obligations, tax theory, legal relationship, tax research.

JEL Classification: K34 


\section{Introduction}

Legal relationship is the basic tool for regulating and systematizing numerous legal institutions [Filipek 1968: 5-7]. At the same time, there are few problems related to the issue of legal relationships that are not disputed [Ziembiński 1980: 312], however it has been also pointed out that both the conceptual apparatus regarding the legal relationship itself as well as its elements are unclear, and furthermore, the disputes relate to issues such as its ontological nature, its subject, object, or the characteristics of situations arising for various entities involved in the legal relationship [Ziembiński1980: 312].

In many branches of law, the concept of legal relationship serves as a reference for other more specific categories and legal institutions. Hence, in order to fulfil the function of a common ground for these categories and concepts, this concept must take into account the distinctive nature of the normative material of a given national law system, whose generalization allows for developing such a concept that will constitute a common denominator facilitating the comparison of legal phenomena irrespective of changes in the content of legal provisions.

The starting point for developing the concept of a legal relationship appropriate to a given branch of law should undoubtedly be its most general concepts appearing in the theory of law. However, the concept taken directly and without any changes from the theory of law and applied to individual branches of law would not meet the practical goal of facilitating the organization, understanding, and application of the provisions of these branches of law. What one can say "in general" about legal relationships is only that they involve some assignment of correlative legal situations of some specific entities [Longchamps 1964: 4547]. Therefore, in order to construct the concept of a legal relation useful for a given branch of law, legal provisions and institutions of a given branch of law should be taken into account. Only in this way the concept of a legal relationship can fulfil the functions referred to hereinabove.

\section{The state of research on the tax law relationship in the light of foreign tax law science}

Legal relationship does not play the same role in every branch of law. This concept is not used in the study of substantive criminal law or constitutional law [Ziembiński 1980: 335]. Undoubtedly, the concept of a legal relationship is important for the analysis of the provisions of tax law. This is due to the fact that from the very beginning, the tax law 
studies have been built around the concept of legal relationship, and the concept itself has been used to analyze and regulate the provisions of this branch of law [Kalinowski 2013]. This concept in tax law rose in significance after 1919, when the Reichsabgabenordnung Act was adopted in Germany: it regulated, among others, general provisions of the tax law and was based on the concept of an obligatory legal relationship and whose content concealed a large theoretical load provoking the doctrine of financial law to undertake a broad scientific discussion on the concept of a tax law relationship. In a relatively short time, a number of publications appeared in which individual elements of the tax liability theory were analyzed. The discussion on this issue was primarily conducted by German scholars: A. Hensel, H. Nawiasky, O. Bühler and E. Blumenstein. An important contribution was also made by Italian finance scholars, such as B. Grizotti, A.D. Giannini. D. Jarach, A. Amatucci or E. Vanoni. A little later, the South American financial law studies, led by $D$. Jarach and M. Pugliese, joined the discussion, as well the Spanish finance law scholars represented in particular by F. Sainz de Bujanda and J. J. Fereiro Lapatza [Kalinowski 2013]. Since the issue of the tax law relationship started being discussed, a number of publications have been written that either comprehensively cover this issue or analyze specific issues related to this relationship [ex. Hensel 2005; Giannini 1937; Nawiasky 1926; Blumenstein 1926; Jarach 1941; Micheli 1989].

The review of publications of the above mentioned authors devoted to tax law relationships indicates that they are strongly rooted in the tax systems of particular countries. Consequently, there is no uniform concept of the tax law relationship but rather many concepts. What is more, the concepts developed in the tax systems of particular countries are significantly different from each other, however assumptions concerning developing the concept of a tax law relationship is more of universal nature. These differences are numerous and relate to both the nature of the tax law relationship and its individual elements.

The first contentious issue regarding the tax law relationship, which is still being relatively extensively discussed in the tax law studies, is the nature of the obligatory tax law relationship itself. First, according to O. Mayer's [Mayer 1903: 132-143], F. Schneider's [Schneider 1918: 4-9, 21-23, 32], O. Bühler's [Bühler 1927: 102-109] or V. E. Orlando's [Orlando 1894: 121] views, the tax law relationship is an authority relationship. Those authors pointed out that this relationship was shaped by the tax authority by means of a unilateral administrative act. This concept is contrasted with the concept of the tax relationship as an obligation relationship presented by F. Myrbach-Rheinfeld [MyrbachRheinfeld 1910: 103-125], H. Nawiasky [Nawiasky 1982: 53-54], E. Blumenstein 
[Blumenstein 1926: 14, 24] or D. Jarach [Jarach 1982: 57-64]. Supporters of that view pointed out that the content of a material legal relationship arose from the provisions of substantive tax law, and thus could not be shaped by tax authorities. This means that in this relationship, taxpayers and tax authorities are in the same position. Thus, the tax creditor and the tax debtor are in the same relationship as the creditor and the debtor in private law liability relationships. This allows for assuming that the structure of the tax relationship and the civil law liability relationship are the same. Finally, an indirect theory between the above-mentioned concepts regarding the nature of the tax law relationship is the so-called theory of tax functions [ex. Micheli 1989: 107, 161, 240]. It assumes that the taxpayer is subject to tax authority, while their intersubjective position is shaped by the tax administration by means of an administrative act. According to this theory, the implementation of a tax event results in a tax debt situation, a commitment to behaviours that are not fulfilled solely by the obligation to pay a certain amount. The traditional relationship between the right to receive tax and the obligation to pay it does not constitute all the behaviours set by the norm and hence, these rights and obligations cannot be reduced to the tax law relationship.

Another issue related to the tax law relationship is its structure. This issue also raises many doubts that focus on the question of whether the tax law consists of many legal relationships built around individual rights or obligations or whether one should rather develop one legal relationship would cover all these rights and obligations.

A significant part of tax law studies assumes that tax law relationships should be constructed as simple relationships. It is therefore argued that when one speaks of a tax liability, this is primarily an obligation to pay the tax. It is in the centre, while all other liabilities and obligations revolve around it. The obligation to pay tax does not all in itself constitute the entire tax relationship, as there is a whole range of legal relationships that spread around it, forming somewhat concentric circles, and whose purpose is to enable the implementation of the first obligation [Nawiasky 1982: 55-57; see also Kalinowski, 2018: 108-110]. D. Jarach also strongly emphasized the need to recognize tax relationships as simple relationships. As he explicitly stated, there is no tax relationship as a complex relationship covering many entities and many obligations and liabilities. There is also no tax relationship covering formal obligations and liabilities. On the other hand, there is a basic substantive law relationship arising by law, whose participants are: on the one hand, an entity that has a claim for a cash benefit, and on the other, entities that are obliged to provide it [Jarach 1982: 54-55]. In the Italian studies, this view is explicitly accepted by a number of authors, including A. Fantozzi, F. Tezauro or P. Russo, and by J. Ferreiro 
Lapatzain in the Spanish studies. Finally, in the South American studies, this view is shared by Valdés Costa, D. Yamashita, or P. de Barros Carvalho.

The emergence of the concept of a tax law relationship as a complex relationship should be associated with Italian tax law studies. This was first introduced by A. D. Giannini [Giannini 1937, 1965]. According to him, all rights and obligations imposed on a taxpayer, tax authorities, and various third parties make up a tax law relationship with a complex content. Its essential and fundamental part, as well as the ultimate goal of the institution of tax, is the taxpayer's obligation to pay a certain amount of tax. This obligation may be referred to as a tax debt, and the correlative right of a public entity may be called a claim. However, all other rights and obligations arising from the tax relationship may be called tax rights and obligations.

In tax law studies, there is also the view that tax relationships should distinguish between the legal relationship of debt and the separate legal relationship of liability [Soares Martinez, 1963: 77-80]. The internal structure of the tax law relationship remains equally contentious among the scholars.

In tax law studies, the elements determining legal relationships are not always uniformly defined. In the theory of law, it is pointed out that the elements determining specific legal relationships are: a set of entities appearing in a given legal relationship, behaviours considered to be the subject of the relationship, and facts resulting in a legal relationship in a given legal system [Ziembiński 1980: 336]. There is also the view according to which the elements of the legal relationship are the subjects of this relationship, correlated obligations and rights, the subject of the legal relationship, and the so-called legal facts [Lang, Wróblewski, Zawadzki 1986: 379]. In the tax law, there is the view that the elements of the tax law relationship are: an active entity entitled to a benefit, i.e. a tax claim, in other words a tax creditor; a passive entity or a tax debtor who bears the name of the taxpayer; the subject of the tax, i.e. a cash benefit that is the tax; and the legal event that the statute links with the creation of the tax relationship [D. Jarach 1984: 65]. One can also find a view that the elements determining the basic tax law relationship are: an active entity, a passive entity, the subject of the benefit, which is an amount of money, a claim that is a tax right, and a debt that is a legal obligation [De Barros Carvalho 2008; 7577].

When characterizing the basic tax relationship, it is sometimes stated that its structure is analogous to the structure of a private law obligation [Giannini 1937:76]. However, this is not a general view. In particular, the German tax law studies have indicated that a tax 
liability it is characterized by a number of features that differ it from the private law obligation [Hensel 2005: 153-154; Blumenstein 1926: 14, 24]. G. Ingrosso also believes that the tax liability belongs to public law and at the same time is an autonomous institution, separate from other institutions of the latter branch of law. He also indicates that although the term "tax debt" used in tax law seems to come from the private law terminology, it has nothing to do with private law. A tax claim is externally similar to a private law monetary claim, but it has antithetical content in its material aspect [Ingrosso 1937: 69].

However, the reason for the biggest scholarly debate was and still is the issue of tax capacity [see Kalinowski 2019].

The basic tax law relationship is always a bilateral relationship. Traditionally, the parties to this relationship are referred to as the active party and the passive party.

The active party to this relationship, that is entitled to receive the tax, is the state or other public-law institution represented by tax authorities. There may be some exceptions to this rule in that under certain tax systems, public law corporations and even private law entities may be eligible [Giannini 1937: 65-71; González Sánchez 2001: 141-143].

The concept of the passive party to a tax law relationship is often understood in a relatively narrow manner, as it is deemed to be only the taxpayer. However, it has been pointed out that this term can be understood in two ways. First, it can be given a broad legal meaning, according to which it is any person who is liable to pay tax, irrespective of the legal title under which they are obliged to pay it. On the other hand, in the strictly techno-legal sense, passive entities are the persons who are defined as such in a given legal order [Sainz de Bujanda 1993: 221].

There is no dispute in the studies that the taxpayer is the passive subject of the basic tax law relationship within the strict techno-legal meaning of the word. It is indicated that other passive entities may also appear in this relationship. The latter view is, however, not indisputable. At the same time, the disputes concern both the principle itself, and thus the question whether these other entities obliged to pay the tax can be considered entities of the basic tax law relationship, as well as the list and classification of these entities. They are a derivative of two factors: views on the structure of the tax law relationship and the content of legal regulations contained in particular legal systems.

The view that, apart from a taxpayer, other passive entities may appear in the basic tax law relationship, dominates in the studies of tax law. They most often considered to be tax bearers (withholding agents) and persons responsible for the taxpayer's liabilities. The 
justification for this view is seen in the content of positive law regulations. On the other hand, in many Latin American countries, the general provisions of tax law recognize passive entities of the tax relationship as taxpayers and persons responsible for the taxpayer's liabilities.

This approach to the passive party to a tax law relationship should be considered justified without any reservations in relation to the tax bearer. Their duty always consists in fulfilling a required tax payment, and thus they are in a legal relationship with the active entity. The position of the responsible person in a tax law relationship should be assessed slightly differently. If one rejects the dualistic theory which recognizes that there are two legal relationships, i.e. the debt relationship and the liability relationship, and recognizes the existence of one and uniform basic tax law relationship, then one should consider that its passive party is also the responsible person for the taxpayer's liability. However, if the dualistic theory is accepted, then one should conclude that this entity does not act as a party to the debt relationship, but only to the liability relationship.

However, there are scholars who claim that only the taxpayer is the passive entity in this relationship [Ferreiro Lapatza 2010: 270-274, 325-342; see also Dominguez Rodicio 1984: 133]. It is a consequence of the adoption of specific assumptions regarding the perception of tax law relationships as simple relationships [Ferreiro Lapatza 2010: 270-274, 325-342].

Provisions of the tax law doctrine regarding the passive entities in tax law relationships are focused on two separate issues. First, attempts have been made to identify the group of entities that may find themselves in a passive entity situation. These considerations have been carried out at the most general level, in isolation from specific tax law relationships, and their purpose was to determine to whom grant the capacity in tax law. More specifically, an attempt was made to determine whether only entities with the civil legal capacity, i.e. natural persons and legal persons, can be taxpayers, or whether tax law can create its own entities, in isolation from the capacity structures of other branches of law, including in isolation from the civil legal capacity. Secondly, it has been analyzed the issue of who could be the debtor of a specific tax and other issues related to the tax capacity of a specific tax, such as the passive solidarity of taxpayers or their responsibility for a tax liability [Berliri 1967: 329-330].

Another contentious issue related to the tax law relationship that has not been definitively resolved is the issue of the moment and sources of a tax debt. For F. Myrbach-Rheinfeld, the creator of the concept of the obligatory tax relationship, the tax debt (Abgabenschuld) is a legal relationship, as only when it was created, the debtor could be considered liable 
[Myrbach-Rheinfeld 1910]. According to other representatives of the tax law studies, the tax law relationship itself arises as soon as the circumstances provided for in the tax standard hypothesis occur [Giannini 1956: 159; Jèze 1937]. On the other hand, there have been doubts as to the events resulting in tax debt and tax liability.

As indicated above, F. Myrbach-Rheinfeld himself argued that the occurrence of the circumstances provided for in the statute does not lead to the emergence of a tax debt and the corresponding claim of the state, but only the competence of the administrative authorities to determine the person who is in debt and the amount of the tax amount to be paid. Determination of these circumstances takes place by imperative, as a result of issuing the payment order. However, it is only the service of this act to the taxpayer that creates the tax debt [Myrbach-Rheinfeld 1910: 204]. H. Nawiasky also expressed the same position according to which, in direct taxes, it was only the act of assessment that led to the creation of a tax liability and the corresponding claim for payment of the amount of tax. However, for the establishment of a tax law relationship and the emergence of an obligation to pay the tax in indirect taxes, which do not provide for issuing tax decisions, the existence of an event specified in the tax statute is sufficient. A similar view has been also expressed by a number of French scholars, in particular by G. Jèze. He took the position that every person who met the conditions set out in the tax law should have been established by the tax authority to be the debtor of a certain amount of tax. The occurrence of an event specified in these provisions is therefore a condition for the tax authority to exercise its competence to issue a decision by which a tax liability arises. The source of its creation is therefore a unilateral expression of will by the tax authority [Jèze 1936: 190 and seq].

However, a very large group of tax law scholars opposed this view, stating that the tax liability arose as soon as the event specified in the tax standard occurred, while the administrative act by which the amount of the tax liability was determined was only declaratory. This view was expressed, among others, by A. D. Giannini, D. Jarach or G. Morange. This last view also gained support in the later study of tax law, which undoubtedly had an impact on subsequent codifications of tax law.

Undoubtedly, the widest debate about the tax law relationship was caused by the issue of the cause of the tax liability. This concept first appeared in the works of B. Griziotti [Griziotti 1929:268-287]. He pointed out that in all periods of history, one could find some common criteria for the fair and ethical distribution of the various forms of public dues among the citizens, which according to him are: 
1) general benefits for an individual due to them belonging to a political, economic or social group,

2) special benefits that an entity obtains in connection with the provision of public services by the state,

3) the individual ability of each member of society to meet the public dues required of them in relation to living in a social group.

Only the first two factors are the "reasons" justifying the burden of an individual with public dues.

Griziotti took the view that the use of the concept of a legal reason (causa) is fully justified also when applied to public law relationships, as public law obligations, as all relationships having property effects, must have their practical purpose-which is the reason for the legal relationship-in order to be justified. In the absence of such a reason, these relationships have no legitimacy.

According to him, in tax law relationships, this practical purpose which is the cause for the tax liability (causa impositionis) is based on general or special benefits that the taxpayer obtains as a result of actions taken by the state, or as a result of belonging to the state, society or the economy of the nation or a given state. It is because of the possibility of obtaining these benefits that the citizen decides to be part of the group or aspires to join it. These reasons also set limits in which the state may require tax considerations from citizens. Although these limits are of an ethical and social nature, they also have their legal basis. For this reason, the tax should be proportional not only to the amount of resources the taxpayer has at their disposal but also to the benefits that they derive from belonging to a political organization, and therefore it should take into account the nature and degree of belonging to that organization.

However, the aforementioned causa impositionis not only sets the limits of the state's right to impose a tax but also must assess the right to collect tax in each individual tax relationship. In this situation, the right of the state to receive tax will be excluded even then, the taxpayer will be entitled to the consideration but will not be able to obtain either general or specific benefits from belonging to the state. The tax collected by the state, despite the taxpayer's failure to obtain these benefits, would be arbitrary and illegal and constitute extortion.

Griziotti's views found few supporters. D. Jarach was one of them, however, he accepted that theory to a limited extent, taking the view that the legal reasons for tax should be sought in the act of taxation, or in the act of will of the tax authority which imposes a tax 
after establishing the existence of subjective and individual tax conditions provided by law. In order to issue this act, the authority must search for the reason that led the legislator to associate these or other legal effects with such an event. According to him, the lack of such an identified reason means that the authority cannot issue a tax decision resulting in taxpayer being charged with a tax [Jarach, 1984: 91-108].

However, Griziotti's views regarding the legal reason for taxation had much more opponents than supporters. These views were severely criticized by both Italian and foreign tax law scholars. It was pointed out that tax law relationships were established on the basis of applicable law and that they were caused by the occurrence of events regulated in the tax norms hypothesis and this was the only legally relevant reason for the establishment of a tax relationship [Giannini 1974: 82-87; Trotabas 1937: 34 and siq.; Blumenstein 1939: 355 and seq.; Vanoni 1932: 109-112].

\section{Research on the concept of tax relationship in Polish tax law science}

The above paper's review shows that the number of publications on the tax law relationship in the foreign tax law research is significant but the majority of theses they make are disputed. The analysis of foreign publications on the tax law relationship leads also to the conclusion that the concepts of this relationship are strongly rooted in the tax systems of particular countries. This, in turn, means that they cannot be directly used in the regulation and application of the Polish tax law. In addition, one can see that these concepts or their elements stand in clear opposition to each other. Therefore, it is necessary either to opt for one of them or to propose a completely different solution than the ones adopted in the research and which would be the result of a generalization of the tax regulations in force in Poland. This is an issue also in case of other countries that did not develop a clear concept of tax law relationship.

In the Polish tax law studies, there have also been several publications on the tax law relationship [ex. Nita 1999; Mastalski 1985; Dzwonkowski 2003; Kalinowski 2019; Kalinowski 1999; Kalinowski 2013; Rusek 2007; Olesińska, 2000; Olesińska 2017], but their analysis leads to the conclusion that some of it analyzed only certain elements of the tax law relationship (e.g. tax obligations and liabilities). In turn, the most extensive work devoted to this issue [Nita 1999] is clearly an attempt to confront German proposals regarding the tax law relationship with the Polish tax law regulations. Furthermore, that study did not discuss in detail all disputed issues related to the tax law relationship. In fact, the concept of tax law relationship that would be based on the norms of Polish tax law has 
not been developed. Only selected elements of this relationship dominate in the Polish tax law study publications. Due to the lack of a full and coherent concept of a tax law relationship, which would be rooted in the regulations of the Polish tax law, there is no clear concept of such a relationship that would allow for solving legal doctrine problems appearing in the Polish tax law and which would also contribute to further theoretical research.

The lack of such an adequate tool leads to negative consequences in the process of applying tax law. This fact alone justifies making an attempt to develop the concept of tax law relationship that would be based on the norms of Polish tax law and generalize some of its features to be a useful tool used in the process of regulating and systematizing the institutions of Polish tax law. The analysis of its the case law shows that the administrative courts do not have a clear concept of the tax law relationship, which leads to judgements that raise a number of doubts. A relevant practical example of such consequences are the Supreme Administrative Court's judgments regarding tax overpayment, tax capacity in property tax or value added tax.

In the resolution of the Supreme Administrative Court dated from of December 3, 2012, the Court stated that in the light of art. $70 \S 1$ and art. $208 \S 1$ of the Act of August 29, 1997 Tax Ordinance [Journal of Laws of 2012, item 749, as amended], after the expiry of the limitation period, it is not allowed to conduct tax proceedings and rule on the amount of a tax liability that has expired by payment [Supreme Administrative Court, I FPS 1/12]. From the arguments of the Supreme Administrative Court it might be read that it equates expiry of tax liability with expiry of tax law relationship, and the same - tax liability with legal tax relationship. Meanwhile, the identification of the tax obligation with the tax law relationship is a loose association resulting from associations with the terminology used in the civil law. In the civil law, the term obligation is sometimes used to describe legal relationship an obligation type. Hence, probably the court assumed that since in civil law the word "obligation" is used for the term of legal relationship, this is also the case in the tax law. Consequently, it considered that the time-limit "tax obligation" is an equivalent to the term "tax law relationship". However, the term "tax obligation" is not used in Polish tax law as a synonym for a tax law relationship, but it used for legal designation of the obligation of the tax debtor consisting in payment of tax debt. Therefore, it was used to define the debt, being only one element of the tax law relationship. Meanwhile, Polish Tax Ordinance defines the tax obligation as a legal obligation, not as a tax law relationship.

In turn, in the judgement of Provincial Administrative Court in Gdańsk dated from 19 January 2011 dealing with tax subjectivity, the court ruled that the status of the taxpayer 
in a real estate tax is a civil partnership, not its partners [Provincial Administrative Court, I SA / Gd 1014/10], while in the judgement of the Supreme Administrative Court of 31 May 2017, the court stated that as a taxpayer in this tax might be regarded only the entity that meets cumulatively both the subjective and objective conditions specified in Local Tax Act [Journal of Laws 2010, No. 95, item 631 as amended]. In the case of the companies without legal personality, in the Supreme Administrative Court's opinion, the status of a real estate taxpayer within the meaning of the above-mentioned act, is assigned with the companies with a real estate in the form of: ownership, independent ownership, perpetual usufruct or possession under the conditions specified in art. $3 \mathrm{sec} .1$ point 4 of the said Act. This leads the court to the conclusion, that a civil law partnership may not acquire rights on its own behalf, including ownership of real estate and other rights in rem, as well as obligation rights (e.g. conclude lease agreements on its own behalf). In the absence of different regulations in tax acts, such categories as: ownership, perpetual usufruct, dependent and independent possession, trade in these rights or the ability to perform legal transactions in this respect should be assessed according to the provisions of civil law [Supreme Administrative Court, II FSK 1261/15]. Interestingly, with regard to the same type of company under the excise duty provisions the Court decided that the taxpayer is a partnership without legal personality as an organization of partners, and not the partners themselves, despite the fact that, in terms of civil law, they were granted legal subjectivity and in the light of civil law they were carrying out activities falling within the scope of this tax [Supreme Administrative Court GSK 936/15; Supreme Administrative Court, GPS $1 / 15]$.

As it has been indicated above that relatively numerous studies on the tax law relationship can be found in foreign papers. However, they are based on the regulations of foreign tax law. To some extent, they can also be undoubtedly helpful in the Polish tax law research and in the process of applying the law, as well as provide a starting point for developing such a concept that would take into account the distinctive nature of Polish tax regulations. There is a need for developing the concept of a tax law relationship that would meet this requirement. Such a concept will undoubtedly contribute to a better systematization, understanding, and application of the Polish tax regulations. Its individual elements would also allow for a more in-depth analysis of such detailed issues as tax capacity, the legal nature of the so-called self-calculation of tax or the mechanism for the emergence and expiry of tax liabilities. However, developing the concept of tax law relationship, which would be based on the regulations of Polish tax law and generalize some of its features to be a useful tool used in the process of regulating and systematizing 
the institutions of Polish tax law requires solving several research problems. Admittedly, these assumptions apply to the Polish tax system, they are universal and are applicable in the event of developing the concept of a tax law relationship, also for other legal systems.

First of all it is necessary to examine the findings of the theory of law regarding the legal relationship and its elements, as it is impossible to develop the theory of the tax law relationship without taking into account the general findings made by the theory of law.

Secondly, it is necessary to examine the concepts of tax law relations presented in the foreign tax research papers.

Thirdly, based on the findings of the theory of law, the current concepts of a tax law relationship and its elements, as well as based on the examination of judicial decisions and provisions of Polish tax law, the concept of a tax law relationship should be formulated.

Research under the first research problem should aim to achieve the following specific research objectives:

- the first research problem should be establishing the manner of determining a legal relationship by theory of law;

- the second research problem should be determining whether it is possible by means of a legal relationship to describe a legal situation in which a law imposes an obligation on one person to behave towards another person;

- the third research problem should be to determine the characteristics of particular types of legal relationships identified in legal theory;

- the fourth research problem should be determining the list of elements determining legal relationships that appear in theoretical and legal studies and in the research of individual branches of law;

- the fifth research problem will be to examine the extent to which the theory of law can be useful in developing a model of tax law relationship.

Making arrangements within the above-mentioned research problems should be only a starting point for further research and aimed at developing a model of tax law relationship. The findings of the theory of law cannot be indifferent to the theory of tax law relations, as the issue of the latter legal relationship overlaps with the findings of the theory of law.

Research under the second research problem should aim to achieve the following specific research objectives:

1) determining the particular elements determining the tax law relationship listed by foreign tax law scholars; 
2) determining the views of foreign tax law scholars on the content of particular elements of the tax law relationship;

3) confronting the views of foreign tax law scholars on the content of particular elements of the tax law relationship with the foreign tax legislation in order to determine whether and what impact it had on these views;

4) determination of discrepancies in foreign tax law studies regarding individual elements establishing the tax law relationship and the determination of their source;

5) determining common trends in foreign tax law studies regarding individual elements establishing the tax law relationship.

Making arrangements under the second research problem will be aimed at determining to what extent certain specific issues regarding the tax law relationship have been sufficiently analysed and ceased to raise controversy in the global tax law studies.

Research under the third research problem should aim to achieve the following specific research objectives:

1) the first research problem should be determining the views of Polish tax law scholars on the content of particular elements of the tax law relationship;

2) determining the statements of administrative courts regarding the content of particular elements of the tax law relationship;

3) determining divergences and common views in Polish tax law study regarding particular elements establishing the tax law relationship;

4) determining the reasons for the divergence of views of Polish tax law studies on the content of particular elements of the tax law relationship;

5) analysis of the applicable provisions of Polish tax law in order to identify the group that can be used to develop a model of a tax law relationship embedded in Polish law;

6) developing a model of a tax law relationship.

When implementing this last detailed research problem, it is necessary to resolve the detailed issues referred to in item two regarding the nature of the tax law relationship and the elements that determine it.

The first issue that has to be examined is the nature of the tax law relationship. During the 20th century, this relationship was initially perceived as an authority relationship, and then as an obligatory relationship. Undoubtedly, the tax law relationship is an administrative law relationship. The administrative authorities shape this relationship through an 
administrative act and apply penalties in the event of violations of orders and prohibitions. However, the content of this relationship must be shaped on the basis of and within the limits of the law, since the tax authorities do not have the so-called special administrative authority (Das besondere Gewaltverhältnis). The executive authorities may, on its basis, shape the obligations of the other party to the relationship, which do not result from any statutory basis, thus interfering in the sphere of its right without specific statutory authorization. Therefore, once this relationship has been formed, the executive has the power to demand only what arises from the administrative act.

It cannot be denied, of course, that in tax law, the administrative bodies may also have their power increased or strengthened by receiving some discretionary powers to impose certain obligations on taxpayers. Such a phenomenon occurs in particular in the field of tax procedures. Thus, special administrative authority can only be discussed in terms of procedural and legal relationships.

On the other hand, resolving the issue of treating tax law relations as simple or complex relations is a derivative of the function that this category has in the tax law studies. It has been pointed out that it is a tool for regulating and systematizing the law. Therefore, the adopted ratio model should fulfil this function as much as possible. Starting from this point of view and taking into account the usefulness of the above-mentioned models of tax law relationships for the analysis of applicable tax law, one should come to the conclusion that the model in which these relations are developed around one entitlement or obligation is more appropriate. In particular, this applies to the basic legal relationship, the content of which is the obligation to pay tax. However, the function of these relationships should always be kept in mind. They are established in connection with the existence of a basic legal relationship, the content of which is the obligation to pay tax and which are intended to facilitate the enforcement of this obligation. Hence, the model of a complex tax law relationship may prove to be useful for theoretical analysis, when one wants to present the connections between particular tax rights and obligations.

Turning to the issue of the internal structure of the tax law relationship, one should reiterate that the structure of a legal relationship is nowadays a commonly accepted tool in law studies for analysing the legal situation of various entities set out in legal situations where the rights and obligations of one of them are correlated with rights and obligations of the other. It is used in a number of branches of law, including in particular civil law where it was originally developed and from where it was adopted by other branches of law. The notion of a legal relationship was implemented to tax law from the law of obligations, and the first one to use this model of legal relationship and develop the tax law 
studies around it was F. Myrbach-Rheinfeld. Hence, the issue of elements determining basic legal relations does not raise much controversy in tax law. The tax law study transfers them directly from the law of obligations. At the same time, some of the scholars recognize that the basic tax law relationship is identical to the obligatory civil law relationship. They encourage the transfer of civil law terminology to describe liabilities.

This approach does not seem right. At first glance, the internal structure of a basic tax law relationship resembles the structure of an obligatory civil law relationship in the sense that, as in any legal relationship, it is possible to distinguish the entities, the subject, and its content. However, this is only an external similarity that cannot affect the final position as to the identical nature of both legal relationships. To make the assessment, it is more important to determine what is the content of these relationships, and therefore what is the characteristics of the legal situations assigned to the subjects of these relations.

Analysing from this point of view the basic tax law relationship, one can see that the legal situation of its passive party is the same as the legal situation of the obligor of the civil law liability relationship. They have a legal obligation to fulfil a property benefit by paying the tax amount.

This is different in case of the right of the active party to the legal relationship. In the obligatory relationship under civil law, the creditor's right is related to the legal possibility to make use of this right. Meanwhile, the right of the active part to a basic tax relationship is combined with the obligation to use it. It is therefore a related competence. Thus, an administrative body may neither renounce it nor dispose of it any other way. Failure to observe this circumstance may lead to the blurring of the outlines of tax law and to attempts to apply other branches of law, including civil law, to tax law relationships.

On the other hand, the proposal of implementation of a dualistic concept of a basic tax law relationship to the tax law study should be assessed as scientifically interesting. One can perceive it as a reference to the concept of connected standards, in which primary and secondary standards are distinguished. The latter are standards indicating the manner of appropriate behaviour, while the former regulate the legal consequences of violating the first standard. Undoubtedly, this allows for a deeper analysis of a number of tax law institutions, such as the legal position of third parties responsible for taxpayer's liabilities. It can also be used in the process of analyzing tax law relationship dynamics.

The analysis of the issue of passive tax capacity leads to the conclusion that only the taxpayer is the subject of the basic tax law relationship. On the other hand, the tax bearer, 
the collector and the third party responsible for the liabilities of the first entity are subjects of separate relationships which are, however, connected with the first relationship.

While referring to the taxpayer's capacity itself, one should come to the conclusion that this normative trait is not an internal and prior trait of this entity but it is characteristic of everyone who finds themselves in the situation regulated by the tax law norm provision.

A preliminary analysis of the issue of the legal cause of tax (causa impositionis) leads to the conclusion that it cannot be associated with the facts that give rise to a tax relationship. This relationship arises as a result of an event regulated in the legal norm provision. It may arise as a relationship that is not fully specified, and for its specification, it is necessary to issue a tax decision, or it may arise as it is fully specified. However, causa impositionis is an issue related to the legislative process and the principle of tax justice included in it.

\section{Summary}

There is no doubt that there is a need for developing the concept of a tax law relationship, however in many countries and the same in the case of Poland such a concept is not clear. The lack of the clear concept of tax law relationship leads to negative consequences in the process of applying tax law as such a difficulties in systematization, understanding, and application of tax law regulations and its institutions.

As it has been indicated the number of publications on the tax law relationship in the foreign tax law research has been published, nevertheless the analysis of foreign publications on the tax law relationship leads to the conclusion that the concepts of this relationship are strongly rooted in the tax systems of particular countries and cannot be directly used in the regulation and application of the tax law in other country. Moreover, the concepts developed in the tax systems of particular countries are significantly different from each other. These differences are numerous and relate to both the nature of the tax law relationship and its individual elements. Consequently, when developing the concept of a tax law relationship foreign scientific papers on the tax law relationship should be used as a starting point, though of the concept is not clearly developed as in the case of Poland the distinctive nature of particular tax regulations of a given tax system and some of its features should be taken into account in further research work. 


\section{References}

Berliri A., Principi di diritto tributario [Principles of tax law], vol. I, Milan: A Giuffrè, 1967

Berliri, A. Principii di diritto tributario [Principles of tax law], vol. II, Milan: A Giuffrè, 1972

Blumenstein E., La causa nel diritto tributario svizzero [The cause in Swiss tax law], Rivista di Diritto Finanziario e Scienza dele Finanze [Journal of Financial Law and Financial Science], vol. 3, no. 3, 1939

Blumenstein E., Schweizerisches Steuerrecht [Swiss tax law], vol. 1, Tübingen: Mohr, 1926

Brzeziński B., Olesińska A., Pustuł J. (eds), Odpowiedzialność i sankcje w prawie podatkowym [Liability and sanctions in tax law], Toruń: Towarzystwo Naukowe Organizacji i Kierowania "Dom Organizatora" [Scientific Society for Organisation and Management „Organizer's House"], 2017

De Barros Carvalho P., Obligación trubutaria: definición, acepciones, estructura interna y límites conceptuales [Tax obligation: definition, meanings, internal structure and conceptual boundaries], in: C. García Novoa, C. Hoyos Jiménez (eds), El tributo y su aplicación: perspectivas para el siglo XXI [Taxation and its application: prospects for the 21st century], t. I, Madrid, Barcelona, Buenos Aires: Marcial Pons 2008

Dominguez Rodicio J.R., El sujeto pasivo en la Ley General Tributaria [The taxpayer in general tax law], Crónica Tributaria [The tax law Chronicle] vol. 50, 1984

Dzwonkowski H., Powstawanie i wymiar zobowiązań podatkowych [Creation and assessment of tax liabilities], Warsaw: Dom Wydawniczy ABC [ABC Publishing House], 2003

Ferreiro Lapatza J.J., Instituciones de Derecho financiero [Institutions of financial law], Madrid: Marcial Pons, 2010

Filipek J., Stosunek administracyjnoprawny [Administrative law relationship], Cracow: Wydawnictwo Uniwersytetu Jagiellońskiego [Jagiellonian University Publishing House], 1968

Giannini A.D., II rapporto giuridico d'imposta [The tax law relationship], Milan: A. Giuffrè 1937

Giannini A.D., Istituzioni di diritto tributario [Institutions of tax law], Milan: A. Giuffrè, 1974

González Sánchez M., El Estado, los entes locales y otros sujetos [The State, local authorities and other subjects], in: A. Amatucci, E. González García, C. Trzaskalik (eds.), Tratado de Derecho tributario [Treatise on tax law], vol. II, Bogotá: Editorial Temis, 2001

Griziotti B., Principi de politica, diritto e scienza delle finanze [Principles of politics, law and finance], Padova: CEDAM, 1929

Hensel A., Derecho tributario [Tax law], Madrid-Barcelona: Marcial Pons, 2005

Ingrosso G., Istituzioni di Diritto Finanziario. Vol. II: Le entrate dello stato. Imposte e tasse. Entrate patrimoniali [Institutions of financial law. Vol. II: State revenues. Taxes and duties. Patrimonial revenue], Giornale degli Economisti e Rivista di Statistica [Journal of Economists and Review of Statistics], vol. 77, no. 11, 1937

Jarach D., El hecho imponible: teoría general del derecho tributario sustantivo [The taxable event: a general theory of substantive tax law], Buenos Aires: Abeledo-Perrot, 1984

Jèze G., Le fait générateur de l'impôt. Contribution à la théorie de la créance d'impôt [The taxable event. Contribution to the theory of the tax liability], RDP, 1937

Kalinowski M., Hans Nawiasky's views on tax law and tax-law relations, Studia luridica Toruniensia, t. XXII, Toruń, 2018

Kalinowski M., Narodziny i kształtowanie się współczesnej koncepcji stosunku podatkowoprawnego [The birth and formation of the modern concept of the tax law relationship], Toruński Rocznik Podatkowy, 2013

Available at:

http://www.trp.umk.pl/download/trp2013/NARODZINY_I_KSZTA\%C5\%81TOWANIE_SIE_ WSPOLCZESNEJ_KONCEPCJISTOSUNKU_PODATKOWEGO.pdf), accessed: March $3^{\text {rd }}$, 2021

Kalinowski M., Podmiotowość prawna podatnika [Legal subjectivity of the taxpayer], Toruń: Towarzystwo Naukowe Organizacji i Kierowania "Dom Organizatora” [Scientific Society for Organisation and Management "Organizer's House"], 1999

Kalinowski M., Podmioty bierne stosunku podatkowoprawnego. Przyczynek do teorii podmiotowości podatkowej [Passive subjects of the tax law relationship. A contribution to the theory of tax subjectivity], Toruń: Towarzystwo Naukowe Organizacji i Kierowania „Dom Organizatora" [Scientific Society for Organisation and Management "Organizer's House"], 2019 
Kalinowski M., Przedmiot podatku [The subject of tax], Toruń: Towarzystwo Naukowe Organizacji i Kierowania „Dom Organizatora” [Scientific Society for Organisation and Management „Organizer's House”], 2013

Lang W., Wróblewski J., Zawadzki S., Teoria państwa i prawa [Theory of law and state], Warsaw: Wydawnictwo Naukowe PWN [PWN Scientific Publishing], 1986

Longchamps F., Pojęcie stosunku prawnego w prawie administracyjnym [Concept of legal relationship in administrative law], Acta Universitatis Wratislaviensis no. 19, Prawo XII [Law XII], 1964

Mastalski R., Obowiązek podatkowy i zobowiązanie podatkowe [Tax liability and tax obligation], in: M. Wersalski (ed.), System instytucji prawno-finansowych PRL [The system of legal and financial institutions of the PRL], vol. III, Wrocław: Ossolineum, 1985

Micheli G. A., Corso do diritto tributario [Tax law course], Turin: UTET, 1989

Myrbach-Rheinfeld F., Précis de droit financier [Handbook of financial law], Paris: V. Giard \& E. Briere, 1910

Nawiasky H., Steuerrechtliche Grundfragen [Basic questions of tax law], München: Pfeiffer, 1926

Nita A., Stosunek podatkowoprawny. Obowiązek i zobowiązanie podatkowe [Tax law relationship. Tax liability and obligation], Cracow: Wolters Kluwer, 1999

Olesińska A., Odpowiedzialność osób trzecich za zobowiązania podatkowe [Liability of third parties for tax debts], Toruń: Towarzystwo Naukowe Organizacji i Kierowania „Dom Organizatora” [Scientific Society for Organisation and Management „Organizer's House”], 2000

Rusek J., Instytucja płatnika w prawie polskim [Institution of a payer in polish law], Warsaw: C. H. Beck, 2007

Sainz de Bujanda F., Lecciones de Derecho Financiero [Lessons in Financial Law], Madrid: Universidad Central De Venezuela, 1993

Soares Martinez P., A obrigação Tributaría. Esboço do seu conceito e do seu desenvolvimento [The tax obligation. Outline of its concept and development], Lisbon: Gabinete de Estudos da DGCl, 1963

Trotabas L., L'applicazione della teoria della causa nel diritto finanziario [The application of the theory of causation in financial law], Rivista di Diritto Finanziario e Scienza dele Finanze [Journal of Financial Law and Financial Science], 1937

Vanoni E., Natura e interpretazione delle leggi tributarie [Nature and interpretation of tax laws], Padva: Cedam, 1932

Ziembiński Z., Problemy podstawowe prawoznawstwa [Basic problems of jurisprudence], Warsaw: Wydawnictwo Naukowe PWN [PWN Scientific Publishing], 1980

\section{Legal acts}

Act of August 29th 1997 Tax Ordinance, Journal of Laws of 2012, item 749, as amended Act of $12^{\text {th }}$ January, 1991 on Local taxes and fees, Journal of Laws 2010, No. 95, item 631 as amended

\section{Court rulings}

Supreme Administrative Court of Poland on $3^{\text {rd }}$ December, 2012, I FPS $1 / 12$

Supreme Administrative Court of Poland on $14^{\text {th }}$ December 2015, GPS 1/15

Supreme Administrative Court of Poland of $21^{\text {st }}$ April 2017 GSK 936/15

Supreme Administrative Court of Poland on 31 $1^{\text {st }}$ May 2017, II FSK 1261/15

Provincial Administrative Court in Gdańsk on $19^{\text {th }}$ January 2011, I SA / Gd 1014/10 